\title{
Molecular challenges of neuroendocrine tumors (Review)
}

\author{
PARTHIK PATEL ${ }^{*}$ and KARINA GALOIAN ${ }^{*}$ \\ Department of Orthopedic Surgery, Miller School of Medicine, University of Miami, Miami, FL 33136, USA
}

Received October 5, 2017; Accepted December 13, 2017

DOI: $10.3892 / 01.2017 .7680$

\begin{abstract}
Neuroendocrine tumors (NETs) are a very heterogeneous group that are thought to originate from the cells of the endocrine and nervous systems. These tumors develop in a number of organs, predominantly in the gastrointestinal and pulmonary systems. Clinical detection and diagnosis are reliable at the late stages when metastatic spread has occurred. However, traditional conventional therapies such as radiation and chemotherapy are not effective. In the majority of cases even surgical resection at that stage is unlikely to produce promising reusults. NETs present a serious clinical challenge, as the survival rates remain low, and as these rare tumors are very difficult to study, novel approaches and therapies are required. This review will highlight the important points of accumulated knowledge covering the molecular aspects of the role of neuroendocrine cells, hormonal peptides, the reasons for ectopic hormone production in NET, neuropeptides and epigenetic regulation as well as the other challenging questions that require further understanding.
\end{abstract}

\section{Contents}

1. Neuroendocrine tumors, neuroendocrine cells and neuropeptides

2. Paraneoplastic syndromes, ectopic hormone secretion

3. Neuropeptides and cancer

4. Signaling pathways and NET

5. Epigenetics in neuroendocrine tumors

6. Conclusions

Correspondence to: Dr Karina Galoian, Department of Orthopedic Surgery, Miller School of Medicine, University of Miami, 1600 NW 10th Avenue, S. 8012, Miami, FL 33136, USA

E-mail: kgaloian@med.miami.edu

${ }^{*}$ Contributed equally

Key words: neuroendocrine tumors, neuropeptides, epigenetics, hormones, signal transduction pathways, mammalian target of rapamycin
1. Neuroendocrine tumors, neuroendocrine cells and neuropeptides

Neuroendocrine tumors (NET) are neoplasms originating in the hormone producing cells of the endocrine system, which is combination of hormone producing endocrine and nerve cells, generally from the neural crest, neuroendocrine islets and stem cells. NETs can manifest functional and nonfunctional symptoms and represent a heterogenous group of neoplasm, such as multiple endocrine neoplasia (MEN), type 1 and 2 medullary thyroid carcinoma, pheochromocytomas/paragangliomas (1-3), gastroentheropancreatic NETs (GEP-NETs) and islet cells (4-10), poorly differentiated/small cell/atypical lung carcinoids (11-17), merkel cell carcinoma (18-21).

NETs are sometimes called carcinoid tumors. Surgical resection alone is often curative in patients with early-stage disease. However, patients with advanced disease may suffer from complications of uncontrolled hormone secretion and usually succumb to fatal complications caused by secreted hormones, but mostly due to tumor progression. Patients with advanced NETs has median survival of 33 months (22). The gene expression profiles proved to be extremely helpful to correlate with tumor classification patterns and correspond to WHO nomenclature. Molecular profiling can identify whether it is malignant pancreatic NETs (pan NETs), PNET or gastrointestinal NETs (GI-NET). The progress with molecular profiling also revealed many important gene targets, among them promising platelet derived growth factor receptor (PDGFR) and RET protooncogene (RET) as new therapeutic targets (23).

While there is vast body of literature covering NETs, there is still confusion sometimes when it comes to grading, nomenclature and classification (24-31).

These tumors synthesize and secrete peptide hormones. Listed here are the most common peptide receptors reported in NETs: Somatostatin receptors, vasoactive intestinal peptide/pituitary adenylate cyclase activating peptide family receptors, cholecystokinin/gastrin receptors, bombesin/gastrin releasing peptide receptors, neurotensin receptors, substance $\mathrm{P}$ receptors, neuropeptide $\mathrm{Y}$ receptors, calcitonin/calcitonin gene-related peptide receptors, atrial natriuretic peptide receptors, glucagon-like-peptide-1 receptors, oxytocin receptors and endothelin receptors 5-hydroxytryptamine, serotonin 5-HT and neuropeptides (32), which can manifest very serious side effects in malignant tumors like heart failure, palpitations and diarrhea. Secretion of the neuropeptides, which can influence metastatic growth and invasiveness is a 


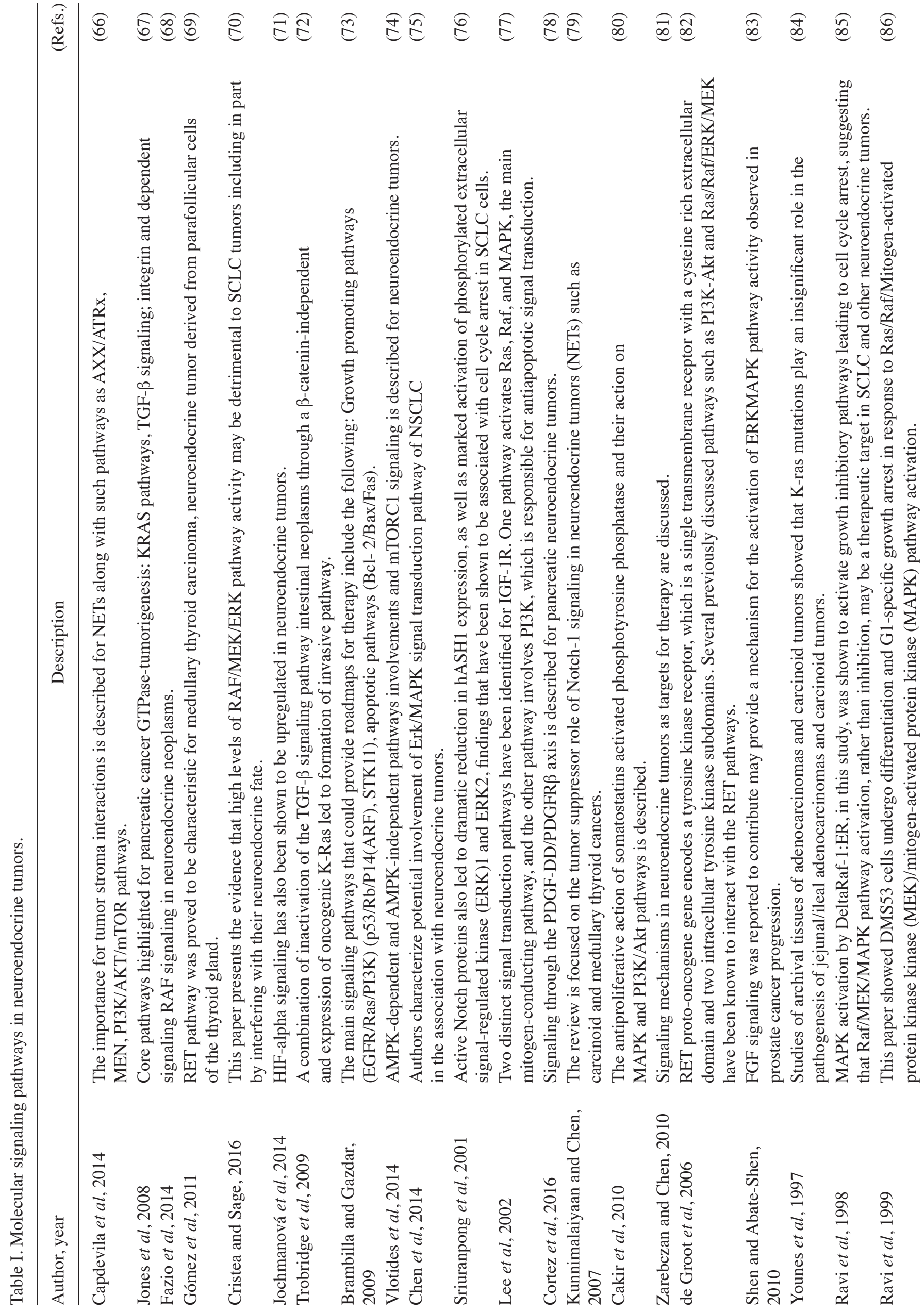




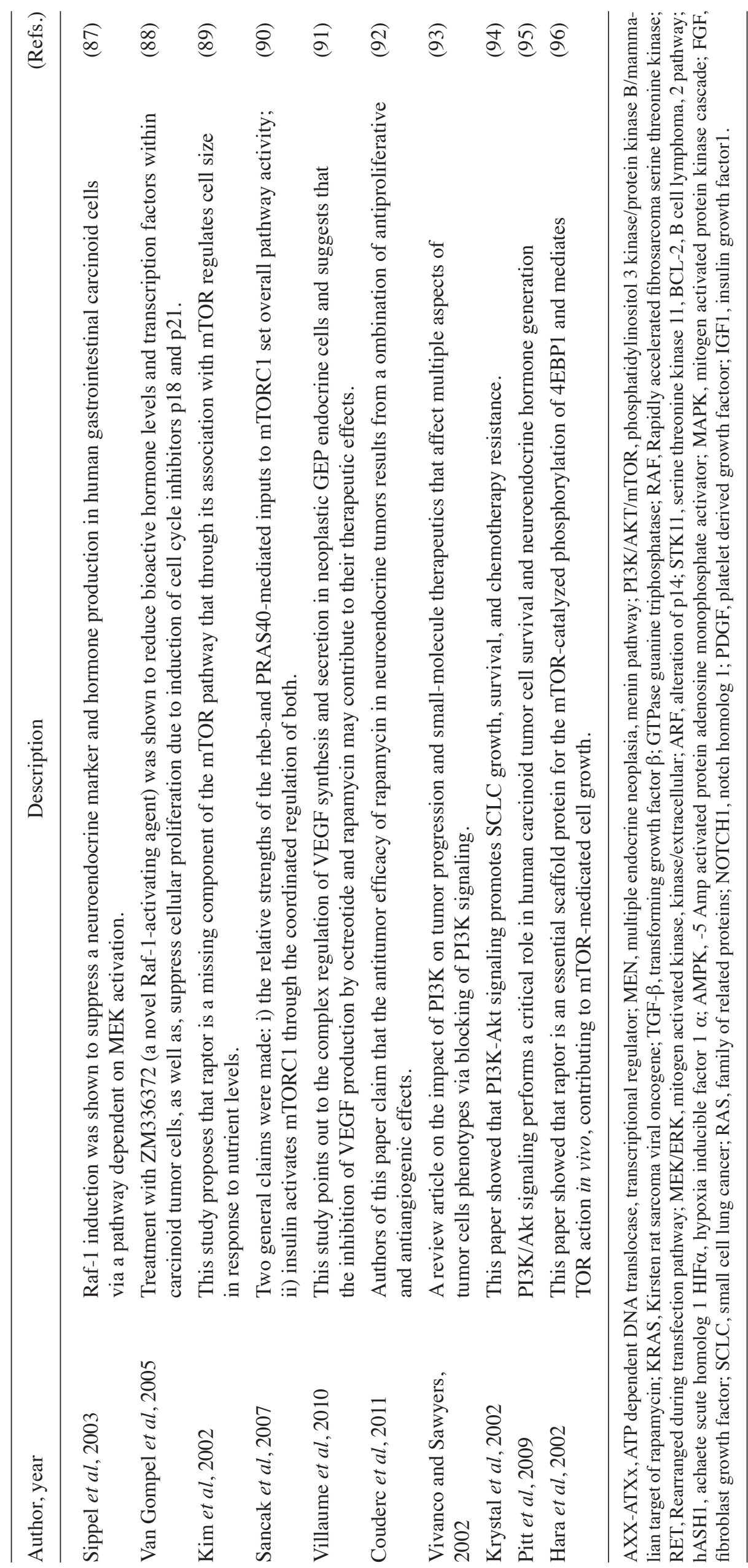


very characteristic feature for NETs. It comes as no surprise that these secreted peptides usually correspond to their normal counterparts. However, in certain tumors like ovarian tumors there are neuroendocrine cells, while in the corresponding normal ovary they are not present (33). The cells of well differentiated NETs produce abundant neurosecretory granules, with diffuse expression of neuroendocrine markers such as chromogranin and synaptophysin. There are differences between well differentiated NETs, which can be either low or intermediate grade, and poorly differentiated NETs that are aggressive and considered high grade, with less resemblance to the normal non transformed cells (31). It is important to understand the difference between differentiation and grade. Differentiation defines how much the neoplastic cells resemble their non-neoplastic counterparts, but the aggressiveness of tumor determines its grade.

There are three hypotheses explaining the occurrence of NETs (34). The first hypothesis is based on the assumption that these neoplasms derive from mature neuroendocrine cells that undergo a dedifferentiation due to occurrence of mutations. The second hypothesis assumes they derive from the progenitors of the neuroendocrine cells that undergo mutations. The third one states they can derive from non neuroendocrine cells that acquire neuroendocrine characteristics during carcinogenesis due to the loss of certain genes.

\section{Paraneoplastic syndromes, ectopic hormone secretion}

Paraneoplastic syndromes (PNSs) are syndromes secondary to substances like hormones, growth factors, cytokines secreted from tumors not related to their specific organ or tissue of origin. The term ectopic hormone syndrome defines hormone production by tumors, which in normal conditions do not carry that function. Ectopic hormone production is only associated with endocrine type of secretion and not with any other type, the earlier PNS is recognised, the better, not only for the correct treatment option but also not to consider PNS as metastatic disease (35-37). There are two theories explaining such a phenomenon $(38,39)$. The pluripotentiality concept is the core of the first theory. The genetic derepression of the genetic material capable to synthesise necessary proteins takes place during cancer development. The second, alternative theory based on assumption that these particular tumors arise only from specialized cells, which have the capacity to produce neuropeptides. Most common tumors are those producing corticotropin-releasing hormone $(\mathrm{CRH})$ and adrenocorticotropic hormone (ACTH), accompanied by Cushings syndrome (40). The tumors which produce growth hormone-releasing hormone (GHRH) with acromegaly symptoms are very rare $(41,42)$. Ectopic antidiuretic hormone (ADH) secretion was also reported $(42,43)$. The tumor derived hormones are those found in the central nervous system, gastrointestinal tract anterior pituitary [iACTH, lipotropin, somatostatin, calcitonin, gastrin, human chorionic gonadotropin (hCG), placental lactogen derived from the fetoplacenta]. Their association with certain placental enzymes and fetal proteins (i. e., carcinoembryonic antigen and o-fetal protein have been used to support the concept of arrested differentiation of tumor cells as the basis for hormone production $(44,45)$.
Pan NETs, islet cell tumors, are rare and originate in the pancreas from endocrine tissue can secrete vinsulin, gastrin, glucagon, and vasoactive intestinal peptide (VIP), which can cause multiple clinical syndromes (46-49).

\section{Neuropeptides and cancer}

Hypothalamic neuropeptides manifest many endocrine, functions in various tissues (50). Growth hormone releasing hormone (GHRH) was isolated from human pancreatic tumors and then identified in human and animal hypothalamus. It was suggested by Nobel Prize laureate Dr Andrew Schally and coworkers that GHRH may function as a growth factor among a large class of mitogens involved in tumorigenesis. This group developed the successful antagonists of GHRH, which were able to inhibit proliferation of number of cancer cell lines (51). GH-RH antagonists, might be beneficial for at least a subset of patients with non small cell lung carcinomas that express $\mathrm{GH}-\mathrm{RH}$ and insulin growth factor receptor (IGF-I) receptors and are dependent on autocrine stimulation by GH-RH and/or IGF-I (52). Peptide hormones can influence the development and growth of many cancers which are not considered classical hormone-dependent tumors. Analogs of somatostatin, bombesin/gastrin-releasing peptide (GRP), luteinizing hormone-releasing hormone (LH-RH) and GHRH can interfere with receptors on tumor cells or intracellular pathways that are important in cell proliferation and in this way inhibit tumor growth (53). The expression of five subtypes of G-protein-coupled transmembrane somatostatin receptors (SSTRs) is very characteristic feature for NETs (54). Octreotide and lanreotide are somatostatin analogs proved to be useful in alleviation of of flushing and diarrhea which are associated with NETs secretion $(55,56)$. The antitumor effect of somatostatin analogs has been established in many clinical trials (57-59).

Somatostatin analogues comprise a significant part in the therapeutic strategy of metastatic NETs. They exert their inhibitory effect by activating somatostatin receptors (which are expressed in about $80 \%$ of well-differentiated NETs. The advantage of these analogs compared to natural somatostatin, is their significantly longer half-life, permitting monthly subcutaneous administration (60). Among the 5 types of SSTRs, SSTR2 is the predominant receptor in NETs (61). The SSTR 2 has the highest density and proved to be associated with overall survival (62-64). Pasireotide (SOM230), a novel somatostatin analog also was reported to have antitumor properties (65).

\section{Signaling pathways and NET}

There are several pathways like mTOR, PI3K-Akt, Ras/Raf/MEK/ERK, Notch pathway and others, which regulate the proliferation of neuroendocrine cancers (Table I) (66-96). Targeting the mTOR pathway, downstream from PI3K-Akt and the Ras/Raf/MEK/ERK pathways has emerged as an effective treatment strategy in the management of advanced NETs. Treatment of carcinoid cells with the mTOR inhibitor, rapamycin, has been shown to decrease tumor growth both in vitro and in vivo (97). Two rapamycin derivatives, temsirolimus and everolimus, have been tested in multicenter, phase II clinical trials on patients with NETs with some promising 
results. The everolimus plus octreotide combined therapeutic treatment demonstrated antitumor effects which is capable to target upstream and downstream key players of mTOR pathway (83-86,98-103). The mTOR complex 1 (mTORC1) inhibitor everolimus and the multikinase (including vascular endothelial growth factor receptor (VEGFR) inhibitor sunitinib were approved by FDA for the treatment of metastatic pNET [Food and Drug Administration, SUTENT ${ }^{\circledR}$ (sunitinib malate) prescribing information: http: //www. accessdata. fda. gov/drugsatfda_docs/label/2011/021938s13s17s18lbl. pdf]

Combination strategy of dual RAS, PI3K/mTOR and MEK inhibition proves to be as an effective treatment for NETs, thus securing the occurrence feedback loops (104). Imatinib is an orally available phenylaminopyrimidine analog which specifically inhibits tyrosine kinase activity associated with c-kit, PDGFR- $\alpha$, PDGFR- $\beta$, and BCR-ABL (105). In laboratory setting Imatinib inhibited cell proliferation and induced apoptosis in both c-kit-positive and c-kit-negative neuroendocrine cells, however it failed in clinical trials (106-108). Experience with the small molecule EGFR tyrosine kinase inhibitor (TKI) gefitinib is an example of thwarted rational target choice. EGFR is over-expressed in NETs, and EGFR inhibitors reduce growth in carcinoid cell lines. Gefitinib in phase II study demonstrated only one positive radiological response among forty patients with carcinoid tumors (109).

Immunoblot analysis revealed that tyrosine kinase target PDGFR- $\alpha$ and $-\beta$ were expressed in PNETs regardless of stage. More importantly, PDGFR- $\beta$ was activated by phosphorylation in the majority of PNETs. Others have reported high levels of expression of PDGFR- $\alpha$, PDGFR- $\beta$, and c-Kit in PNETs, but no assessment of receptor activation has been previously performed (110). In recent years there is body of data supporting important role of targeting Hedgehog, TGF- $\beta$, Notch pathway when considering options for pan NETs treatment. NOTCH1/Achaete-Scute Complex-Like 1 (ASCL1) conserved pathway plays an important role in embryonic development. Its primary role is to ensure proper stem cell maintenance and terminal differentiation. Notch proteins are comprised of four $300 \mathrm{kDa}$ transmembrane receptors and five ligands. Notch induced apoptosis in NETs as it was not the case for epithelial tumors. Indeed, in several publications the tumor suppressor function of Notch, its proapoptotic or its minimal activity is indicated for NETS (111). The phosphatidylinositol 3-kinase (PI3K)/Akt/mammalian target of rapamycin (mTOR) pathway plays very important role in the pathogenesis of pNETs.

NVP-BEZ235, OSI-027 and AZD2014 are novel drugs that target PI3K-AKT-mTOR pathway. BEZ235 is a potent oral multitargeted inhibitor PI3K isoforms and the downstream, mTORC1 and mTORC2 proteins. This drug had much higher activity in NETs than everolimus or its combinations (112). NVP-BEZ235 docks in the active pocket of both molecules and reduces kinase activity of PI3K and mTOR by competing with ATP-binding. Dual PI3K-mTOR blocker NVP-BEZ235 and AZD2014, which is ATP-competitive mTOR blocker were able to overcome this rapalogue resistance (113). NVP-BEZ235 binds to the active pocket of of both molecules and by competing with ATP binding inhibit PI3K and mTOR.

In xEric Baudin. The Ras/Raf/MEK/ERK mitogen pathway can act as, an oncogene, and or tumor suppressor in NETs (114-116). Important to mention the impact of antiangiogenesis inhibitors on NET treatment, for example, VEGFR significantly reduce pancreatic tumor growth or cause regression of established tumors in treated mice, compared with controls, and also disrupt tumor vasculature $(117,118)$. Interestingly, the mutation rate of NET is significantly lower than for other types of cancer, suggesting that they are more genetically stable. Though frequency of mutations had tendency to increase with higher grade, the classical tumor suppressors (like p53, Rb) implicated for tumor development in other tumors, do not play significant role in NET pathogenesis $(119,120)$.

Although mTOR-inhibition leads to significant improvement of progression-free survival in advanced pan NETs, the drug resistance to mTOR inhibition continue to dominate as a major clinical challenge like in many other types of tumors.

\section{Epigenetics in neuroendocrine tumors}

Experimental data suggests that epigenetic programs, such as chromatin and DNA modifications, pre- and posttranscriptional gene regulations by noncoding RNAs are actively involved in changes in gene expressions as a result of stem cell differentiation. Usually self renewal genes are silenced in the differentiating cells, while cell specific genes are very transcriptionally active.

The hypermethylation of RASSF1A promoter was demonstrated to be increased in metastatic tumors (121). DNA methylation at RASSF1A was correlated to worse prognosis in NETs $(122,123)$. Rather than having K-RAS or BRAF mutations, well differentiated NETs have methylation in RASSF1A gene, observed in pancreatic, pulmonary and gastrointestinal tumors $(122,123)$. MEN1 and Daxx/ATRX are part of chromatin modifying complexes the most frequently mutated genes in NETs and mutations of menin and Daxx/ATRX are not mutually exclusive in the same tumor. Tumor suppressors, menin and Daxx, reported to suppress NETs by interacting with each other and epigenetically inhibiting a pro-proliferative gene in endocrine tumors, Mme, via enhancing H3K9me3 modification. MEN1 can interact with histone deacethylases (HDACs) and histone methyltransferases including PRMT5 and SUV39H1, and depending on that act either as activator or supressor of gene transcriptional activity (124-127). Menins role as the regulators in Hox gene expression was well documented $(128,129)$. On the other hand more data is needed to understand the effect of such regulation.

MEN1 was capable of inducing epigenetic modification in pancreas and insulin-like growth factor $2 \mathrm{mRNA}$ binding protein 2 (IGF2BP2) gene was identified as a target subjected to $\mathrm{MEN} 1$ regulation. One of the existing theories stating that the loss of MEN1 can play a role in pNET pathogenesis (130). Menin recruits the $\mathrm{H} 3 \mathrm{~K} 4 \mathrm{me} 3$ histone methyltransferase mixed lineage leukaemia (MLL1) complex, which is utmost important for chromatin remodeling and gene expression regulation (131-133).

In tumors with poor prognosis the promoter hypermethylation was found for such genes as DAPK1, TIMP3, PAX5, HIC1, $C A D M 1$, and many others (134).

It was postulated that chromatin-remodeling pathways was sufficient to drive early oncologic event, given the absence of any other type of cancer mutations and presence of mutations 
of mutations of SWI/SNF complex members, such as ARID1/2 and SMARCA1/2 (135). DNA damage repair, chromatin remodelling, telomere maintenance and mTOR signalling $(136,137)$ were reported as common mutated pathways for PanNET based on genome sequencing analysis. Like in many other tumors hyperactivation of the $\mathrm{Wnt} / \beta$-catenin signaling contributes pNETs progression. The epigenetic silencing via promoter methylation of Wnt inhibitors like Axin 2 and secreted Frizzled-related proteins (SFRPS), Wnt inhibitory factor-1 (WIF-1) and DICKKOPFs (DKKs) were reported, wheras donwregulation of others, such as WIF-1, DKK-1 and $D K K-3$ were caused by $\mathrm{H} 3 \mathrm{~K} 9 \mathrm{me} 1$ increased levels at the promoter (138).

MicroRNAs signatures and histone modifications can be very helpful when it comes to diagnostic uncertainty, whether to identify the subtypes of NETs. One of the attractive features of epigenetic changes is their reversibility, which makes it very appealing as therapeutic targets. miRNAs can serve as biomarkers to distinguish between normal and diseased tissue, miRNAs 103/107/155, for example, can distinguish pan NET from normal pancreatic tissue. Some of miRNAs miRNA-21 and -155 can be upregulated in high grade tumors and not in low grade, others can be detected in metastatic low grade tumors and not normal tissues (139).

Differential gene expression of miRNAs is not a stranger for many tumors, and NETs are not constituting exception. Indeed, miR-183, -488 , and $19 \mathrm{a}+\mathrm{b}$ were upregulated while miR-133a, -145, 146, -222 and -10b were downregulated in metastatic tissue with respect to primary tumors in study with ileal carcinoid tumors (140). Intestinal NETs had different expression profiles of miRNA during different stages of the disease (141). Literature data suggests that miR-129-5p may have an anti-proliferative and anti-metastatic effect in midgut carcinoid tumors (142).

\section{Conclusions}

NETs are arising from neuroendocrine cells. This process should not be confused with phenomenon of occurrence of neuroendocrine cells in non- neuroendocrine neoplasm as a reflection of heterogenous neuroendocrine differentiation in neoplasms. Neuroendocrine cells occur also in tumors which developed in tissues where neuroendocrine cells are not found $(143,144)$. The picture cannot be complete without understanding the involvement of key signal transduction pathways in pathogenesis and therapeutic response of these tumors. One of the predominant pathways is mTOR pathway that was highlighted in this review. The presence of the feedback loops though has to be seriously considered when it comes to combination treatment of somatostatin analogues and mTOR inhibitors $(145,146)$. There still obvious challenges when it comes to drug resistance in clinical trials setting. Somatostatin analogues did not overcome everolimus-induced Akt upregulation. As it is known mTORC inhibitors like everolimus can trigger feedback loops. When used alone, they were able to induce apoptosis, but that effect was lost in combined treatments. Thus, based on the evidence there is no indication of beneficial effect in NETs for cotreatment with everolimus (146). The resistance of treatments also can be explained by presence of the cancer stem cells, which is very controvercial issue for NETs and there is not much evidence for the presence of CSC in these tumors, however some of dual targeted therapies reported to prevent drug resistance (147-151). There is evident lack of reliable biomarkers for correct treatment selection, although there are some for specific NETs, like CDX-2, for example, which is highly specific for metastatic and ileal NETS $(14,152)$. Ki-67 was identified as prognostic biomarker for pancreatic tumors (153-155). There are many open questions and challenges concerning pathogenesis and molecular events leading to NETs and PNS. One of the challenging and unresolved questions is whether ectopic hormone syndrome occurs as a consequence of hormonal secretion gene activation because of malignant trasformation or can be attributed to the intrinsic ability of the primitive cell of origin for this function that was arrested in differentiation process (37-157). The aspect requiring thorough investigation is the modulation of tumor cell behavior by neurohormonal peptides, secreted by neuroendocrine cell population. It still remains to be elucidated how much genetic, epigenetic and chromosomal alterations, can affect the expression or function of the neuropeptides receptors. Unveiling receptor dynamics, density, metabolism or trafficking may help to better understand and predict the effects of analogs in diagnostics and therapy (32). Estimation of neurokinin A levels is assumed to be very useful for more aggressive NETs in their ealy stages. Poor short term survival was reported with neurokinin A concentrations ( $>50 \mathrm{pg} / \mathrm{ml})$ (158). Uniform expression of Angiopoietin-2 (Ang-2) messenger RNA (mRNA) described in endothelial cells of both nontransformed pancreatic tissue and pan NET tissue (159).

The management of neuroendocrine neoplasia is challenging difficult problem, the molecular pathways involved in the pathology of NETs waiting to be explored further and to develop new synergistic treatments impacting prognosis and patients well being (160-162).

\section{Acknowledgements}

The present study was supported in part by a gift from the Ratcliffe Foundation to Miami Center of Orthopedic Research and Education.

\section{References}

1. Takano A, Oriuchi N, Tsushima Y, Taketomi-Takahashi A, Nakajima T, Arisaka Y, Higuchi T, Amanuma M and Endo K: Detection of metastatic lesions from malignant pheochromocytoma and paraganglioma with diffusion-weighted magnetic resonance imaging: Comparison with $18 \mathrm{~F}-\mathrm{FDG}$ positron emission tomography and 123I-MIBG scintigraphy. Ann Nucl Med 22: 395-401, 2008.

2. Brandi ML, Gagel RF, Angeli A, Bilezikian JP, Beck-Peccoz P, Bordi C, Conte-Devolx B, Falchetti A, Gheri RG, Libroia A, et al: Guidelines for diagnosis and therapy of MEN type 1 and type 2. J Clin Endocrinol Metab 86: 5658-5671, 2001.

3. Sherman SI, Brierley JD, Sperling M, Ain KB, Bigos ST, Cooper DS, Haugen BR, Ho M, Klein I, Ladenson PW, et al: Initial analysis of staging and outcomes from a prospective multicenter study of treatment of thyroid carcinoma. Thyroid 83: 1012-1021, 1998.

4. Lawrence B, Gustafsson BI, Chan A, Svejda B, Kidd M and Modlin IM: The epidemiology of gastroenteropancreatic neuroendocrine tumors. Endocrinol Metab Clin North Am 40: 1-18, 2011. 
5. Washington MK, Tang LH, Berlin J, Branton PA, Burgart LJ, Carter DK, Compton CC, Fitzgibbons PL, Frankel WL, Jessup JM, et al: Protocol for the examination of specimens from patients with neuroendocrine tumors (carcinoid tumors) of the small intestine and ampulla. Arch Pathol Lab Med 134: 181-186, 2010.

6. Heymann MF, Joubert M, Nemeth J, Franc B, Visset J, Hamy A, le Borgne J, le Neel JC, Murat A, Cordel S, et al: Prognostic and immunohistochemical validation of the capella classification of pancreatic neuroendocrine tumours: An analysis of 82 sporadic cases. Histopathology 36: 421-432, 2000.

7. Basturk O, Yang Z, Tang LH, Hruban RH, Adsay V, McCall CM, Krasinskas AM, Jang KT, Frankel WL, Balci S, et al: The high-grade (WHO G3) pancreatic neuroendocrine tumor category is morphologically and biologically heterogenous and includes both well differentiated and poorly differentiated neoplasms. Am J Surg Pathol 39: 683-690, 2015.

8. Strosberg JR, Cheema A, Weber J, Han G, Coppola D and Kvols LK: Prognostic relevance of a novel American Joint Committee on Cancer staging classification for neuroendocrine tumors of the pancreas. J Clin Oncol 29 3044-3049, 2011.

9. Jann H,Roll S, Couvelard A,Hentic O,Pavel M,Müller-Nordhorn J, Koch M, Röcken C, Rindi G, Ruszniewski P, et al: Neuroendocrine tumors of midgut and hindgut origin: Tumor-node-metastasis classification determines clinical outcome. Cancer 117 3332-3341, 2011.

10. Pape UF, Jann H, Müller-Nordhorn J, Bockelbrink A, Berndt U, Willich SN, Koch M, Röcken C, Rindi G and Wiedenmann B: Prognostic relevance of a novel TNM classification system for upper gastroenteropancreatic neuroendocrine tumors Cancer 113: 256-265, 2008 .

11. Przygodzki RM, Finkelstein SD, Langer JC, Swalsky PA, Fishback N, Bakker A, Guinee DG, Koss M and Travis WD: Analysis of p53, K-ras-2 and C-raf-1 in pulmonary neuroendocrine tumors. Correlation with histological subtype and clinical outcome. Am J Pathol 148: 1531-1541, 1996.

12. Travis WD, Rush W, Flieder DB, Falk R, Fleming MV, Gal AA and Koss MN: Survival analysis of 200 pulmonary neuroendocrine tumors with clarification of criteria for atypical carcinoid and its separation from typical carcinoid. Am J Surg Pathol 22: 934-944, 1998

13. Fink G, Krelbaum T, Yellin A, Bendayan D, Saute M, Glazer M and Kramer MR: Pulmonary carcinoid: Presentation, diagnosis, and outcome in 142 cases in Israel and review of 640 cases from the literature. Chest 119: 1647-1651,2001.

14. Srivastava A and Hornick JL: Immunohistochemical staining for CDX-2, PDX-1, NESP-55 and TTF-1 can help distinguish gastrointestinal carcinoid tumors from pancreatic endocrine and pulmonary carcinoid tumors. Am J Surg Pathol 33: 626-632, 2009.

15. Cardillo G, Sera F, Di Martino M, Graziano P, Giunti R, Carbone L, Facciolo F and Martelli M: Bronchial carcinoid tumors: Nodal status and long-term survival after resection. Ann Thorac Surg 77: 1781-1785, 2004.

16. Okike N, Bernatz PE and Woolner LB: Carcinoid tumors of the lung. Ann Thorac Surg 22: 270-275, 1976.

17. Moran CA, Suster S, Coppola D and Wick MR: Neuroendocrine carcinomas of the lung: A critical analysis. Am J Clin Pathol 131: 206-221, 2009

18. Wollina U, Langer D and Tchernev G: Mushroom-like skin tumours: Report of three cases. Open Access Maced J Med Sci 5: 515-517, 2017.

19. Gerer KF, Erdmann M, Hadrup SR, Lyngaa R, Martin LM, Voll RE, Schuler-Thurner B, Schuler G, Schaft N, Hoyer S and Dörrie J: Preclinical evaluation of NF- $\mathrm{KB}$-triggered dendritic cells expressing the viral oncogenic driver of Merkel cell carcinoma for therapeutic vaccination. The Adv Med Oncol 9: 451-464, 2017

20. Sauer CM, Haugg AM, Chteinberg E, Rennspiess D Winnepenninckx V, Speel EJ, Becker JC, Kurz AK and Zur Hausen A: Reviewing the current evidence supporting early B-cells as the cellular origin of Merkel cell carcinoma. Crit Rev Oncol Hematol 116: 99-105, 2017.

21. Murakami I, Takata K, Matsushita M, Nonaka D, Iwasaki T, Kuwamoto S, Kato M, Mohri T, Nagata K, Kitamura Y, et al: Immunoglobulin expressions are only associated with MCPyV-positive Merkel cell carcinomas but not with MCPyV-negative ones: Comparison of prognosis. Am J Surg Pathol 38: 1627-1635, 2014
22. Kulke MH, Siu LL, Tepper JE, Fisher G, Jaffe D, Haller DG, Ellis LM, Benedetti JK, Bergsland EK, Hobday TJ, et al: Future directions in the treatment of neuroendocrine tumors: Consensus report of the National Cancer Institute Neuroendocrine Tumor clinical trials planning meeting. J Clin Oncol 29: 934-943, 2011.

23. Mosquera C, Koutlas NJ and Fitzgerald TL: Localized high-grade gastroenteropancreatic neuroendocrine tumors: Defining prognostic and therapeutic factors for a disease of increasing clinical significance. Eur J Surg Oncol 42: 1471-1477, 2016.

24. Kim JY and Hong SM: Recent updates on neuroendocrine tumors from the gastrointestinal and pancreatobiliary Tracts. Arch Pathol Lab Med. 140: 437-448, 2016.

25. Schindl M, Kaczirek K, Kaserer K and Niederle B: Is the new classification of neuroendocrine pancreatic tumors of clinical help? World J Surg 24: 1312-1318, 2000.

26. Yao JC, Hassan M, Phan A, Dagohoy C, Leary C, Mares JE, Abdalla EK, Fleming JB, Vauthey JN, Rashid A and Evans DB: One hundred years after 'carcinoid': Epidemiology of and prognostic factors for neuroendocrine tumors in 35,825 cases in the United States. J Clin Oncol 26: 3063-3072, 2008.

27. Vinik AI and Renar IP: Neuroendocrine tumors of carcinoid variety. In: Endocrinology. De Grool L (ed). WB Saunders, Philadelphia, PA, pp2803-pp2814, 1995.

28. Oberg K and Castellano D: Current knowledge on diagnosis and staging of neuroendocrine tumors. Cancer Metastasis Rev 30: 3-7, 2011.

29. Klimstra DS, Modlin IR, Adsay NV, Chetty R, Deshpande V, Gönen M, Jensen RT, Kidd M, Kulke MH, Lloyd RV, et al: Pathology reporting of neuroendocrine tumors: Application of the Delphic consensus process to the development of a minimum pathology data set. Am J Surg Pathol 34: 300-313, 2010.

30. Travis WB, Brambilla E, Muller-Hermelink and Harris CC: Pathology and genetics of tumours of lung, pleura, thymus and heart. IARC Press, Lyon 10: 1240-1242, 2004.

31. Klimstra DS, Modlin IR, Coppola D, Lloyd RV and Suster S: The pathologic classification of neuroendocrine tumors: A review of nomenclature, grading and staging system. Pancreas 39: 707-712, 2010.

32. Pelosi G, Volante M, Papotti M, Sonzogni A, Masullo M and Viale G: Peptide receptors in neuroendocrine tumors of the lung as potential radionuclide diagnosis and therapy. Q J Nucl Med Mol Imaging 50: 272-287, 2006.

33. Bosman FT: Neuroendocrine cells in non-endocrine tumors: What does it mean? Ges Path 81: 62-72, 1996.

34. Cueto A, Burigana F, Nicolini A and Lugnani F: Neuroendocrine tumors of the lung: Histological classification, diagnosis, traditional and new therapeutic approaches. Curr Med Chem 21: 1107-1116, 2014.

35. Kaltsas G, Androulakis II, de Herder WW and Grossman AB: Paraneoplastic syndromes secondary to neuroendocrine tumours. Endocr Relat Cancer 17: R173-R193, 2010.

36. Keffer JH: Endocrinopathy and ectopic hormones in malignancy. Hematol Oncol Clin North Am 10: 811-823, 1996.

37. Bollanti L, Riondino G and Strollo F: Endocrine paraneoplastic syndromes with special reference to the elderly. Endocrine 14: 151-157, 2001.

38. Hollander IJ and Aponte GE: Ectopic hormone production by malignant tumors. Ann Clin Lab Sci 9: 268-274, 1979.

39. Das S, Mukherjee K, Bhattacharya S and Chowdhury JR: Ectopic production of placental hormones (human chorionic gonadotropin and human placental lactogen) in carcinoma of the uterine cervix. Cancer 51: 1854-1857, 1983.

40. Mnif Feki M, Mnif F, Kamoun M, Charfi N, Rekik N, Bennaceur B, Mnif L, Sellami Boudawara T and Abid M: Ectopic secretion of GHRH by a pancreatic neuroendocrine tumor associated with an empty sella. Ann Endocrinol (Paris) 72: 522-525, 2011.

41. Glikson M, Gil-Ad I, Galun E, Dresner R, Zilberman S, Halperin Y, Okon E, Laron Z and Rubinow A: Acromegaly due to ectopic growth hormone-releasing hormone secretion by a bronchial carcinoid tumour. Dynamic hormonal responses to various stimuli. Acta Endocrinol (Copenh) 125: 366-371, 1991.

42. Garby L, Caron P, Claustrat F, Chanson P, Tabarin A, Rohmer V, Arnault G, Bonnet F, Chabre O, Christin-Maitre S, et al: Clinical characteristics and outcome of acromegaly induced by ectopic secretion of growth hormone-releasing hormone $(\mathrm{GHRH})$ : A French nationwide series of 21 cases. GTE Group. J Clin Endocrinol Metab 97: 2093-2104, 2012. 
43. Hubold C and Brabant G: Ectopic hormone secretion by neuroendocrine tumors. Internist (Berl) 53: 145-151, 2012 (In German).

44. Baylin SB and Mendelsohn G: Ectopic (inappropriate) hormone production by tumors: Mechanisms involved and the biological and clinical implications. Endocrin Rev 1: 45-77, 1980.

45. Yamasaki R, Saito H, Sano T, Kameyama K, Yoshimoto K, Hosoi E, Matsumura M, Harada K and Saito S: Ectopic growth hormone-releasing hormone (GHRH) syndrome in a case with multiple endocrine neoplasia type I. Endocrinol Jpn 35: 97-109, 1988.

46. Hochwald SN, Zee S, Conlon KC, Colleoni R, Louie O, Brennan MF and Klimstra DS: Prognostic factors in pancreatic endocrine neoplasms: An analysis of 136 cases with a proposal for low-grade and intermediate-grade groups. J Clin Oncol 20: 2633-2642, 2002.

47. Hoang MP, Hruban RH and Albores-Saavedra J: Clear cell endocrine pancreatic tumor mimicking renal cell carcinoma: A distinctive neoplasm of von Hippel-Lindau disease. Am J Surg Pathol 25: 602-609, 2001.

48. Klöppel G, Perren A and Heitz PU: The gastroenteropancreatic neuroendocrine cell system and its tumors: The WHO classification. Ann N Y Acad Sci 1014: 13-27, 2004.

49. Kamp K, Feelders RA, van Adrichem RC, de Rijke YB van Nederveen FH, Kwekkeboom DJ and de Herder WW: Parathyroid hormone-related peptide (PTHrP) secretion by gastroenteropancreatic neuroendocrine tumors (GEP-NETs): Clinical features, diagnosis, management, and follow-up. J Clin Endocrinol Metab 99: 3060-3069, 2014.

50. Schally AV, Comaru-Schally AM, Nagy A, Kovacs M, Szepeshazi K, Plonowski A, Varga JL and Halmos G: Hypothalamic hormones and cancer. Front Neuroendocrinol 22: 248-291, 2001

51. Szereday Z, Schally AV, Varga JL, Kanashiro CA, Hebert F, Armatis P, Groot K, Szepeshazi K, Halmos G and Busto R: Antagonists of growth hormone-releasing hormone inhibit the proliferation of experimental non-small cell lung carcinoma. Cancer Res 63: 7913-7919, 2003.

52. Szepeshazi K, Schally AV, Groot K, Armatis P, Hebert F and Halmos G: Antagonists of growth hormone-releasing hormone (GH-RH) inhibit in vivo proliferation of experimental pancreatic cancers and decrease IGF-II levels in tumours. Eur J Cancer 36 $128-136,2000$

53. Szepeshazi K, Block NL and Schally AV: The use of peptide analogs for the treatment of gastrointestinal, pancreatic, liver and urinary bladder cancers. Horm Mol Biol Clin Investig 1: 103-110, 2010.

54. Cidon EU: New therapeutic approaches to metastatic gastroenteropancreatic neuroendocrine tumors: A glimpse into the future. World J Gastrointest Oncol 9: 4-20, 2017.

55. Wolin EM: The expanding role of somatostatin analogs in the management of neuroendocrine tumors. Gastrointest Cancer Res 5: 161-168, 2012.

56. Baldelli R, Barnabei A, Rizza L, Isidori AM, Rota F, Di Giacinto P, Paoloni A, Torino F, Corsello SM, Lenzi A and Appetecchia M: Somatostatin analogs therapy in gastroenteropancreatic neuroendocrine tumors: Current aspects and new perspectives. Front Endocrinol (Lausanne) 5: 7, 2014.

57. Sidéris L, Dubé $P$ and Rinke A: Antitumor effects of somatostatin analogs in neuroendocrine tumors. Oncologist 17: 747-755, 2012.

58. Boden G, Ryan IG, Eisenschmid BL, Shelmet JJ and Owen OE: Treatment of inoperable glucagonoma with the long-acting somatostatin analogue SMS 201-995. N Engl J Med 314: 1686-1689, 1986.

59. Vezzosi D, Bennet A, Rochaix P, Courbon F, Selves J, Pradere B, Buscail L, Susini C and Caron P: Octreotide in insulinoma patients: Efficacy on hypoglycemia, relationships with Octreoscan scintigraphy and immunostaining with anti-sst2A and anti-sst5 antibodies. Eur J Endocrinol 152: 757-67, 2005.

60. Pollak MN and Schally AV: Mechanisms of antineoplastic action of somatostatin analogs. Proc Soc Exp Biol Med 217: 143-152, 1998.

61. Arnold R, Trautmann ME, Creutzfeldt W, Benning R, Benning M, Neuhaus C, Jurgensen R, Stein K, Schafer H, Bruns C, et al: Somatostatin analogue octreotide and inhibition of tumour growth in metastatic endocrine gastroenteropancreatic tumours. Gut 38: 430-438, 1996.

62. Oberg K, Krenning E, Sundin A, Bodei L, Kidd M, Tesselaar M, Ambrosini V, Baum RP, Kulke M, Pavel M, et al: Delphic consensus assessment: Imaging and biomarkers in gastroenteropancreatic neuroendocrine tumor disease management. Endocr Connect 5: 174-187, 2016
63. Oberg K and Jelic S; ESMO Guidelines Working Group: Neuroendocrine gastroenteropancreatic tumors: ESMO clinical recommendation for diagnosis, treatment and follow-up. Ann Oncol 20: 150-153, 2009 .

64. Qian ZR, Li T, Ter-Minassian M, Yang J, Chan JA, Brais LK, Masugi Y, Thiaglingam A, Brooks N, Nishihara R, et al: Association between somatostatin receptor expression and clinical outcomes in neuroendocrine tumors. Pancreas 45: 1386-1393, 2016

65. Bruns C, Lewis I, Briner U, Meno-Tetang G and Weckbecker G: SOM230: A novel somatostatin peptidomimetic with broad somatotropin release inhibiting factor (SRIF) receptor binding and a unique antisecretory profile. Eur J Endocrinol 146: 707-716, 2002.

66. Capdevila J, Weber M and Pape UF: Continued advances in targeting gastroenteropancreatic neuroendocrine tumors: General discussion. Clin Adv Hematol oncol 12 (12 Suppl 19): S22, 2014.

67. Jones S, Zhang X, Parsons DW, Lin JC, Leary RJ, Angenendt $\mathrm{P}$, Mankoo P, Carter H, Kamiyama H, Jimeno A et al: Core signaling pathways in human pancreatic cancers revealed by global genomic analyses. Science 321: 1801-1806, 2008.

68. Fazio N, Abdel-Rahman O, Spada F, Galdy S, De Dosso S, Capdevila J and Scarpa A: A RAF signaling in neuroendocrine neoplasms: From bench to bedside. Cancer Treat Rev 40: 974-979, 2014

69. Gómez K, Varghese J and Jiménez C: Medullary thyroid carcinoma: Molecular signaling pathways and emerging therapies. J Thyroid Res 2011: 815826, 2011.

70. Cristea $S$ and Sage J: Is the canonical RAF/MEK/ERK signaling pathway a therapeutic target in SCLC? J Thorac Oncol 11: $1233-1241,2016$

71. Jochmanová I, Zelinka T, Widimský J Jr and Pacak K: HIF signaling pathway in pheochromocytoma and other neuroendocrine tumors. Physiol Res 63 (Suppl 2): S251-S262, 2014.

72. Trobridge P, Knoblaugh S, Washington MK, Munoz NM, Tsuchiya KD, Rojas A, Song X, Ulrich CM, Sasazuki T, Shirasawa S and Grady WM: TGF-beta receptor inactivation and mutant Kras induce intestinal neoplasms in mice via a beta-catenin-independent pathway. Gastroenterology 136 1680-1688. e7, 2009.

73. Brambilla E and Gazdar A: Pathogenesis of lung cancer signalling pathways: Roadmap for therapies. Eur Respir J 33: $1485-1497,2009$

74. Vlotides G, Tanyeri A, Spampatti M, Zitzmann K, Chourdakis M, Spttl C, Maurer J, Nölting S, Göke B and Auernhammer CJ: Anticancer effects of metformin on neuroendocrine tumor cells in vitro. Hormones Athens 13: 498-508, 2014.

75. Chen Y, Nowak I, Huang J, Keng PC, Sun H, Xu H, Wei G and Lee SO: Erk/MAP kinase signaling pathway and neuroendocrine differentiation of non-small-cell lung cancer. J Thorac Oncol 9: $50-58,2014$

76. Sriuranpong V, Borges MW, Ravi RK, Arnold DR, Nelkin BD, Baylin SB and Ball DW: Notch signaling induces cell cycle arrest in small cell lung cancer cells. Cancer Res 61: 3200-3205, 2001.

77. Lee HY, Chun KH, Liu B, Wiehle SA, Cristiano RJ, Hong WK, Cohen $\mathrm{P}$ and Kurie JM: Insulin-like growth factor binding protein-3 inhibits the growth of non-small cell lung cancer. Cancer Res 62: 3530-3537, 2002

78. Cortez E, Gladh H, Braun S, Bocci M, Cordero E, Björkström NK, Miyazaki H, Michael IP, Eriksson U, Folestad E and Pietras K: Functional malignant cell heterogeneity in pancreatic neuroendocrine tumors revealed by targeting of PDGF-DD. Proc Natl Acad Sci USA 113: E864-E873, 2016.

79. Kunnimalaiyaan $\mathrm{M}$ and Chen $\mathrm{H}$ : Tumor suppressor role of Notch-1 signaling in neuroendocrine tumors. Oncologist 12: $535-542,2007$

80. Cakir M, Dworakowska D and Grossman A: Somatostatin receptor biology in neuroendocrine and pituitary tumours: Part 1-molecular pathways. J Cell Mol Med 14: 2570-2584, 2010.

81. Zarebczan B and Chen H: Signaling mechanisms in neuroendocrine tumors as targets for therapy. Endocrinol Metab Clin North Am 39: 8018-8010, 2010.

82. de Groot JW, Links TP, Plukker JT, Lips CJ and Hofstra RM: RET as a diagnostic and therapeutic target in sporadic and hereditary endocrine tumors. Endocr Rev 27: 535-560, 2006.

83. Shen MM and Abate-Shen C: Molecular genetics of prostate cancer: New prospects for old challenges. Genes Dev 24: $1967-2000,2010$ 
84. Younes N, Fulton N, Tanaka R, Wayne J, Straus FH II and Kaplan EL: The presence of K-12 ras mutations in duodenal adenocarcinomas and the absence of ras mutations in other small bowel adenocarcinomas and carcinoid tumors. Cancer 79: 1804-1808, 1997.

85. Ravi RK, Weber E, McMahon M, Williams JR, Baylin S, Mal A, Harter ML, Dillehay LE, Claudio PP, Giordano A, et al: Activated Raf-1 causes growth arrest in human small cell lung cancer cells. J Clin Invest 101: 153-159, 1998.

86. Ravi R, Thiagalingam A, Weber E, McMahon M, Nelkin BD and Mabry M: Raf-1 causes growth suppression and alteration of neuroendocrine markers in DMS53 human small-cell lung cancer cells. Am J Respir Cell Mol Biol 20: 543-549, 1999.

87. Sippel RS, Carpenter JE, Kunnimalaiyaan M, Lagerholm S and Chen H: Raf-1 activation suppresses neuroendocrine marker and hormone levels in human gastrointestinal carcinoid cells. Am J Physiol Gastrointest Liver Physiol 285: G245-G254, 2003.

88. Van Gompel J, Kunnimalaiyaan M, Holen K and Chen $\mathrm{H}$ : ZM336372, a Raf-1 activator, suppresses growth and neuroendocrine hormone levels in carcinoid tumor cells. Mol Cancer Ther 4: 910-917, 2005.

89. Kim DH, Sarbassov DD, Ali SM, King JE, Latek RR, Erdjument-Bromage H, Tempst P and Sabatini DM: mTOR interacts with raptor to form a nutrient-sensitive complex that signals to the cell growth machinery. Cell 110: 163-175, 2002.

90. Sancak Y, Thoreen CC, Peterson TR, Lindquist RA, Kang SA, Spooner E, Carr SA and Sabatini DM: PRAS40 is an insulin-regulated inhibitor of the mTORC1 protein kinase. Mol Cell 25: 903-915, 2007.

91. Villaume K, Blanc M, Gouysse G, Walter T, Couderc C, Nejjari M, Vercherat C, Cordier-Bussat M, Roche $C$ and Scoazec JY: VEGF secretion by neuroendocrine tumor cells is inhibited by octreotide and by inhibitors of the PI3K/AKT/mTOR pathway. Neuroendocrinology 91: 268-278, 2010.

92. Couderc C, Poncet G, Villaume K, Blanc M, Gadot N, Walter T, Lepinasse F, Hervieu V, Cordier-Bussat M and Scoazec JY Targeting the PI3K/mTOR pathway in murine endocrine cell lines: In vitro and in vivo effects on tumor cell growth. Am J Pathol 178: 336-344, 2011

93. Vivanco I and Sawyers CL: The phosphatidylinositol 3-Kinase AKT pathway in human cancer. Nat Rev Cancer 2: 489-501, 2002

94. Krystal GW, Sulanke G and Litz J: Inhibition of phosphatidylinositol 3-kinase-Akt signaling blocks growth, promotes apoptosis and enhances sensitivity of small cell lung cancer cells to chemotherapy. Mol Cancer Ther 1: 913-922, 2002.

95. Pitt S, Chen $\mathrm{H}$ and Kunnimalaiyaan M: Inhibition of phosphatidylinositol 3-kinase/Akt signaling suppresses tumor cell proliferation and neuroendocrine marker expression in GI carcinoid tumors. Ann Surg Oncol 16: 2936-2942, 2009

96. Hara K, Maruki Y, Long X, Yoshino K, Oshiro N, Hidayat S, Tokunaga C, Avruch J and Yonezawa K: Raptor, a binding partner of target of rapamycin (TOR), mediates TOR action. Cell 110: 177-189, 2002.

97. Chan J and Kulke M: Targeting the mTOR signaling pathway in neuroendocrine tumors. Curr Treat Options Oncol 15: 365-379, 2014

98. Cerovac V, Monteserin-Garcia J, Rubinfeld H, Buchfelder M, Losa M, Florio T, Paez-Pereda M, Stalla GK and Theodoropoulou M: The somatostatin analogue octreotide confers sensitivity to rapamycin treatment on pituitary tumor cells. Cancer Res 70: 666-674, 2010.

99. Nakakura EK, Sriuranpong VR, Kunnimalaiyaan M, Hsiao EC, Schuebel KE, Borges MW, Jin N, Collins BJ, Nelkin BD, Chen H and Ball DW: Regulation of neuroendocrine differentiation in gastrointestinal carcinoid tumor cells by notch signaling. J Clin Endocrinol Metab 90: 4350-4356, 2005.

100. Ikeda I, Ishizaka Y, Tahira T, Suzuki T, Onda M, Sugimura T and Nagao M: Specific expression of the ret proto-oncogene in human neuroblastoma cell lines. Oncogene 5: 1291-1296, 1990.

101. Plaza Menacho I, Koster R, van der Sloot AM, Quax WJ, Osinga J, van der Sluis T, Hollema H, Burzynski GM, Gimm O, Buys CH, et al: RET-familial medullary thyroid carcinomamutants Y791F and S891A activate a Src/JAK/STAT3 pathway, independent of glial cell. Cancer Res 65: 1729-1737, 2005.

102. Bousquet C, Lasfargues C, Chalabi M, Billah SM, Susini C, Vezzosi D, Caron P and Pyronnet S: Clinical review: Current scientific rationale for the use of somatostatin analogs and mTOR inhibitors in neuroendocrine tumor therapy. J Clin Endocrinol Metab 97: 727-737, 2012.
103. Duran I, Kortmansky J, Singh D, Hirte H, Kocha W, Goss G, Le L, Oza A, Nicklee T, Ho J, et al: A phase II clinical and pharmacodynamic study of temsirolimus in advanced neuroendocrine carcinomas. Br J Cancer 95: 1148-1154, 2006.

104. Valentino JD, Li J, Zaytseva YY, Mustain WC, Elliott VA, Kim JT, Harris JW, Campbell K, Weiss H, Wang C, et al: Cotargeting the PI3K and RAS pathways for the treatment of neuroendocrine tumors. Clin Cancer Res 20: 1212-1222, 2014.

105. Lankat-Buttgereit B, Horsch D, Barth P, Arnold R, Blöcker S and Göke R: Effects of the tyrosine kinase inhibitor imatinib on neuroendocrine tumor cell growth. Digestion 71: 131-140, 2005.

106. Perkins J, Boland P, Cohen SJ, Olszanski AJ, Zhou Y, Engstrom P and Astsaturov I: Successful imatinib therapy for neuroendocrine carcinoma with activating Kit mutation: A case study. J Natl Compr Canc Netw 6: 847-852, 2014.

107. Samlowski WE, Moon J, Tuthill RJ, Heinrich MC, Balzer-Haas NS, Merl SA, DeConti RC, Thompson JA, Witter MT, Flaherty LE and Sondak VK: A phase II trial of imatinib mesylate in merkel cell carcinoma (neuroendocrine carcinoma of the skin): A Southwest Oncology Group study (S0331). Am J Clin Oncol 33: 495-499, 2010.

108. de Groot JW, Zonnenberg BA, van Ufford-Mannesse PQ, de Vries MM, Links TP, Lips CJ and Voest EE: A phase II trial of imatinib therapy for metastatic medullary thyroid carcinoma. J Clin Endocrinol Metab 92: 3466-3469, 2007.

109. Lawrence B, Gustafsson BI, Kidd M and Modlin I: New pharmacologic therapies for gastroenteropancreatic neuroendocrine tumors. Gastroenterol Clin North Am 39: 615-628, 2010

110. Fjallskog ML, Lejonklou MH, Oberg KE, Eriksson BK and Janson ET: Expression of molecular targets for tyrosine kinase receptor antagonists in malignant endocrine pancreatic tumors. Clin Cancer Res 9: 1469-1473, 2003.

111. Kunnimalaiyaan M, Vaccaro AM, Ndiaye MA and Chen $\mathrm{H}$ : Overexpression of the NOTCH1 intracellular domain inhibits cell proliferation and alters the neuroendocrine phenotype of medullary thyroid cancer cells. J Biol Chem 281: 39819-39830, 2006.

112. Salazar R, Chris Verslype C, Baudin E, Libutti SK, Yao JC, Buzzoni R, Antonuzzo L, Hubner R, García-Carbonero R, Custodio AB, et al: Phase II studies of BEZ235 in patients with advanced pancreatic neuroendocrine tumors (pNET). J Clin Oncol 33 (15 suppl): S4102, 2015.

113. Vandamme T, Beyens M, de Beeck KO, Dogan F, van Koetsveld PM, Pauwels P, Mortier G, Vangestel C, de Herder W, Van Camp G, et al: Long-term acquired everolimus resistance in pancreatic neuroendocrine tumours can be overcome with novel PI3K-AKT-mTOR inhibitors. Br J Cancer 114: 650-658, 2016.

114. Sippel RS, Carpenter JE, Kunnimalaiyaan M and Chen H: The role of human achaete-scute homolog-1 in medullary thyroid cancer cells. Surgery 134: 866-871, 2003

115. Kappes A, Vaccaro A, Kunnimalaiyaan M and Chen H: ZM336372, a Raf-1 activator, inhibits growth of pheochromocytoma cells. Surg Res 133: 42-45, 2006.

116. Greco A, Borrello MG, Miranda C, Degl'Innocenti D and Pierotti MA: Molecular pathology of differentiated thyroid cancer. Q J Nucl Med Mol Imaging 53: 440-543, 2009.

117. Bergers G, Javaherian K, Lo KM, Folkman J and Hanahan D: Effects of angiogenesis inhibitors on multistage carcinogenesis in mice. Science 284: 808-812, 1999.

118. Parangi S, O'Reilly M, Christofori G, Holmgren L, Grosfeld J, Folkman J and Hanahan D: Antiangiogenic therapy of transgenic mice impairs de novo tumor growth. Proc Natl Acad Sci USA 93: 2002-2007, 1996.

119. Yashiro T, Fulton N, Hara H, Yasuda K, Montag A, Yashiro N, Straus F II, Ito K, Aiyoshi Y and Kaplan EL: Comparison of mutations of ras oncogene in human pancreatic exocrine and endocrine tumors. Surgery 114: 758-763, 1993.

120. Yoshimoto K, Iwahana H, Fukuda A, Sano T, Saito S and Itakura M: Role of p53 mutations in endocrine tumorigenesis: Mutation detection by polymerase chain reaction-single strand conformation polymorphism. Cancer Res 52: 5061-5064, 1992.

121. Zhang HY, Rumilla KM, Jin L, Nakamura N, Stilling GA, Ruebel KH, Hobday TJ, Erlichman C, Erickson LA and Lloyd RV: Association of DNA methylation and epigenetic inactivation of RASSF1A and beta-catenin with metastasis in small bowel carcinoid tumors. Endocrine 30: 299-306, 2006

122. Rahman MM, Qian ZR, Wang EL, Yoshimoto K, Nakasono M, Sultana R, Yoshida T, Hayashi T, Haba R, Ishida M, et al: DNA methyltransferases $1,3 \mathrm{a}$ and $3 \mathrm{~b}$ overexpression and clinical significance in gastroenteropancreatic neuroendocrine tumors. Hum Pathol 41: 1069-1078, 2010. 
123. How-Kit A, Dejeux E, Dousset B, Renault V, Baudry M, Terris B and Tost J: DNA methylation profiles distinguish different subtypes of gastroenteropancreatic neuroendocrine tumors. Epigenomics 7: 1245-1258, 2015.

124. Jiao Y, Shi C, Edil BH, de Wilde RF, Klimstra DS, Maitra A, Schulick RD, Tang LH, Wolfgang CL, Choti MA, et al: DAXX/ATRX, MEN1 and mTOR pathway genes are frequently altered in pancreatic neuroendocrine tumors. Science 331: 1199-1203, 2001.

125. Feng Z, Wang L, Sun Y, Jiang Z, Domsic J, An C, Xing B, Tian J, Liu X, Metz DC, et al: Menin and Daxx interact to suppress neuroendocrine tumors through epigenetic control of the membrane metallo-endopeptidase. Cancer Res 77: 401-411, 2017.

126. Gurung B, Feng Z, Iwamoto DV, Thiel A, Jin G, Fan CM, $\mathrm{Ng} \mathrm{JM}$, Curran T and Hua X: Menin epigenetically represses Hedgehog signaling in MEN1 tumor syndrome. Cancer Res 73: 2650-2658, 2013.

127. Kim H, Lee JE, Cho EJ, Liu JO and Youn HD: Menin, a tumor suppressor represses JunD-mediated transcriptional activity by association with an mSin3A-histone deacetylase complex. Cancer Res 63: 6135-6139, 2003.

128. Hughes CM, Rozenblatt-Rosen O, Milne TA, Copeland TD, Levine SS, Lee JC, Hayes DN, Shanmugam KS, Bhattacharjee A, Biondi CA, et al: Menin associates with a trithorax family histone methyltransferase complex and with the hoxc8 locus. Mol Cell 13: 587-597, 2004.

129. Yokoyama A, Wang Z, Wysocka J, Sanyal M, Aufiero DJ, Kitabayashi I, Herr W and Cleary ML: Leukemia proto-oncoprotein MLL forms a SET1-like histone methyltransferase complex with menin to regulate Hox gene expression. Mol Cell Biol 24: 5639-5649, 2004.

130. Cives M, Simone V, Rizzo FM and Silvestris F: NETs: Organ-related epigenetic derangements and potential clinical applications. Oncotarget 7: 57414-57429, 2016.

131. Agarwal SK, Guru SC, Heppner C, Erdos MR, Collins RM, Park SY, Saggar S, Chandrasekharappa SC, Collins FS, Spiegel AM, et al: Menin interacts with the AP1 transcription factor JunD and represses JunD-activated transcription. Cell 96: $143-152,1999$.

132. Agarwal SK, Kennedy PA, Scacheri PC, Novotny EA Hickman AB, Cerrato A, Rice TS, Moore JB, Rao S, Ji Y, et al: Menin molecular interactions: Insights into normal functions and tumorigenesis. Horm Metab Res 37: 369-374, 2005.

133. Stalberg P, Grimfjärd P, Santesson M, Zhou Y, Lindberg D, Gobl A, Oberg K, Westin G, Rastad J, Wang S, et al: Transfection of the multiple endocrine neoplasia type 1 gene to a human endocrine pancreatic tumor cell line inhibits cell growth and affects expression of JunD, delta-like protein 1/preadipocyte factor-1, proliferating cell nuclear antigen and QM/Jif-1. J Clin Endocrinol Metab 89: 2326-2337, 2004.

134. Stefanoli M, La Rosa S, Sahnane N, Romualdi C, Pastorino R, Marando A, Capella C, Sessa F and Furlan D: Prognostic relevance of aberrant DNA methylation in g1 and g2 pancreatic neuroendocrine tumors. Neuroendocrinology 100: 26-34, 2014.

135. Fernandez-Cuesta L, Peifer M, Lu X, Sun R, Ozretić L, Seidal D, Zander T, Leenders F, George J, Müller C, et al: Frequent mutations in chromatin-remodelling genes in pulmonary carcinoids. Nat Commun 5: 3518, 2014.

136. Scarpa A, Chang DK, Nones K, Corbo V, Patch AM, Bailey P, Lawlor RT, Johns AL, Miller DK, Mafficini A, et al: Whole-genome landscape of pancreatic neuroendocrine tumours. Nature 543: 65-71, 2017.

137. Boora GK, Kanwar R, Kulkarni AA, Pleticha J, Ames M, Schroth G, Beutler AS and Banck MS: Exome-level comparison of primary well-differentiated neuroendocrine tumors and their cell lines. Cancer Genet 208: 374-381, 2015.

138. Kim JT, Li J, Jang ER, Gulhati P, Rychahou PG, Napier DL, Wang C, Weiss HL, Lee EY, Anthony L, et al: Deregulation of Wnt $/ \beta$-catenin signaling through genetic or epigenetic alterations in human neuroendocrine tumors. Carcinogenesis 34: 953-961, 2013

139. Roldo C, Missiaglia E, Hagan JP, Falconi M, Capelli P, Bersani S, Calin GA, Volinia S, Liu CG, Scarpa A and Croce CM: MicroRNA expression abnormalities in pancreatic endocrine and acinar tumors are associated with distinctive pathologic features and clinical behavior. J Clin Oncol 24: 4677-4684, 2006.
140. Ruebel K, Leontovich AA, Stilling GA, Zhang S, Righi A, Jin L and Lloyd RV: MicroRNA expression in ileal carcinoid tumors: Downregulation of microRNA-133a with tumor progression. Mod Pathol 23: 367-375, 2010

141. Li SC, Essaghir A, Martijn C, Lloyd RV, Demoulin JB, Oberg K and Giandomenico V: Global microRNA profiling of well-differentiated small intestinal neuroendocrine tumors. Mod Pathol 26: 685-696, 2013.

142. Døssing KB, Binderup T, Kaczkowski B, Jacobsen A, Rossing M, Winther O, Federspiel B, Knigge U, Kjær A and Friis-Hansen L: Down-regulation of miR-129-5p and the let-7 family in neuroendocrine tumors and metastases leads to up-regulation of their targets Egr1 G3bp1 Hmga2 and Bach1. Genes (Basel) 6: 1-21, 2014.

143. Louwerens JK, Schaberg A and Bosman FT: Neuroendocrine cells in cystic mucinous tumours of the ovary. Histopathology 7 : 389-398, 1983

144. Pagani A, Macrí L, Rosolen A, Toffolatti L, Stella A and Bussolati G: Neuroendocrine differentiation in Ewing's sarcomas and primitive neuroectodermal tumors revealed by reverse transcriptase-polymerase chain reaction of chromogranin mRNA. Nucl Med Mol Imaging 7: 36-43, 1998.

145. Raymond E, Dahan L, Raoul JL, Bang YJ, Borbath I, Lombard-Bohas C, Valle J, Metrakos P, Smith D, Vinik A, et al: Sunitinib malate for the treatment of pancreatic neuroendocrine tumors. N Engl J Med 364: 501-513, 2011.

146. Mohamed A, Romano D, Saveanu A, Roche C, Albertelli M, Barbieri F, Brue T, Niccoli P, Delpero JR, Garcia S, et al: Anti-proliferative and anti-secretory effects of everolimus on human pancreatic neuroendocrine tumors primary cultures: Is there any benefit from combination with somatostatin analogs? Oncotarget 8: 41044-41063, 2017.

147. Zitzmann K, Rüden Jv, Brand S, Göke B, Lichtl J, Spöttl G and Auernhammer CJ: Compensatory activation of Akt in response to mTOR and Raf inhibitors-a rationale for dual-targeted therapy approaches in neuroendocrine tumor disease. Cancer Lett 295: 100-109, 2010.

148. Eichhorn PJ, Gili M, Scaltriti M, Serra V, Guzman M, Nijkamp W, Beijersbergen RL, Valero V, Seoane J, Bernards R, et al: Phosphatidylinositol 3-kinase hyperactivation results in lapatinib resistance that is reversed by the mTOR/phosphatidylinositol 3-kinase inhibitor NVP-BEZ235. Cancer Res 68: 9221-9230, 2008

149. Fisseler-Eckhoff A and Demes M: Neuroendocrine tumors of the lung cancers. Cancers Basel 4: 777-798, 2012.

150. Banerjee J, Papu John AM and Schuller HM: Regulation of nonsmall-cell lung cancer stem cell like cells by neurotransmitters and opioid peptides. Int J Cancer 137: 2815-2824, 2015.

151. Feng L, Wu JB and Yi FM: Isolation and phenotypic characterization of cancer stem-like side population cells in colon cancer. Mol Med Rep 13: 3531-3536, 2015.

152. Jaffee IM, Rahmani M, Singhal MG and Younes M: Expression of the intestinal transcription factor CDX2 in carcinoid tumors is a marker of midgut origin. Arch Pathol Lab Med 130: 1522-1526, 2006.

153. Pelosi G, Bresaola E, Bogina G, Pasini F, Rodella S, Castelli P, Iacono C, Serio G and Zamboni G: Endocrine tumors of the pancreas: Ki-67 immunoreactivity on paraffin sections is an independent predictor for malignancy: A comparative study with proliferating-cell nuclear antigen and progesterone receptor protein immunostaining, mitotic index and other clinicopathologic variables. Hum Pathol 27: 1124-1134, 1996.

154. Clarke MR, Baker EE, Weyant RJ, Hill L and Carty SE: Proliferative activity in pancreatic endocrine tumors: Association with function, metastases and survival. Endocr Pathol 8: 181-187, 1997

155. Ekeblad S, Skogseid B, Dunder K, Oberg K and Eriksson B: Prognostic factors and survival in 324 patients with pancreatic endocrine tumor treated at a single institution. Clin Cancer Res 14: 7798-7803, 2008.

156. Le Roith D, Shiloach J, Roth J and Lesniak MA: Evolutionary origins of vertebrate hormones: Substances similar to mammalian insulins are native to unicellular eukaryotes. Proc Natl Acad Sci USA 77: 6184-6188.

157. Granberg D, Wilander E, Oberg K and Skogseid B: Prognostic markers in patients with typical bronchial carcinoid tumors. J Clin Endocrinol Metab 85: 3425-3430, 2000 
158. Diebold AE, Boudreaux JP, Wang YZ, Anthony LB, Uhlhorn AP, Ryan P, Mamikunian P, Mamikunian G and Woltering EA: Neurokinin A levels predict survival in patients with stage IV well differentiated small bowel neuroendocrine neoplasms. Surgery 152: 1172-1176, 2012.

159. Detjen KM, Rieke S, Deters A, Schulz P, Rexin A, Vollmer S, Hauff P, Wiedenmann B, Pavel M and Scholz A: Angiopoietin-2 promotes disease progression of neuroendocrine tumors. Clin Cancer Res 16: 420-429, 2010.

160. Vinik AI, Anthony L, Boudreaux JP, Go VL, O'Dorisio TM, Ruszniewski P and Woltering EA: Neuroendocrine tumors: A critical appraisal of management strategies. Pancreas 39: 801-818, 2010 .
161. Kvols LK and Woltering EA: Role of somatostatin analogs in the clinical management of non-neuroendocrine solid tumors. Anticancer Drugs 17: 601-608, 2006.

162. Narayanan S and Kunz P: Role of somatostatin analogues in the treatment of neuroendocrine tumors. J Natl Compr Canc Netw 13: 109-117, 2015. 